\title{
Colonization of subsurface microbial observatories deployed in young ocean crust
}

\author{
Beth N Orcutt ${ }^{1,7}$, Wolfgang Bach ${ }^{2}$, Keir Becker ${ }^{3}$, Andrew T Fisher ${ }^{4}$, Michael Hentscher ${ }^{2}$, \\ Brandy M Toner ${ }^{5}$, C Geoffrey Wheat $^{6}$ and Katrina J Edwards ${ }^{1}$ \\ ${ }^{1}$ University of Southern California, Los Angeles, CA, USA; ${ }^{2}$ University of Bremen, Bremen, Germany; \\ ${ }^{3}$ University of Miami, Miami, FL, USA; ${ }^{4}$ Earth and Planetary Science Department, University of California \\ Santa Cruz, Santa Cruz, CA, USA; ${ }^{5}$ University of Minnesota, Twin Cities, St Paul, MN, USA and ${ }^{6}$ Global \\ Undersea Research Unit, University of Alaska, Fairbanks, Moss Landing, CA, USA
}

\begin{abstract}
Oceanic crust comprises the largest hydrogeologic reservoir on Earth, containing fluids in thermodynamic disequilibrium with the basaltic crust. Little is known about microbial ecosystems that inhabit this vast realm and exploit chemically favorable conditions for metabolic activities. Crustal samples recovered from ocean drilling operations are often compromised for microbiological assays, hampering efforts to resolve the extent and functioning of a subsurface biosphere. We report results from the first in situ experimental observatory systems that have been used to study subseafloor life. Experiments deployed for 4 years in young ( $3.5 \mathrm{Ma})$ basaltic crust on the eastern flank of the Juan de Fuca Ridge record a dynamic, post-drilling response of crustal microbial ecosystems to changing physical and chemical conditions. Twisted stalks exhibiting a biogenic iron oxyhydroxide signature coated the surface of mineral substrates in the observatories; these are biosignatures indicating colonization by iron oxidizing bacteria during an initial phase of cool, oxic, iron-rich conditions following observatory installation. Following thermal and chemical recovery to warmer, reducing conditions, the in situ microbial structure in the observatory shifted, becoming representative of natural conditions in regional crustal fluids. Firmicutes, metabolic potential of which is unknown but may involve $\mathbf{N}$ or $\mathbf{S}$ cycling, dominated the post-rebound bacterial community. The archaeal community exhibited an extremely low diversity. Our experiment documented in situ conditions within a natural hydrological system that can pervade over millennia, exemplifying the power of observatory experiments for exploring the subsurface basaltic biosphere, the largest but most poorly understood biotope on Earth.
\end{abstract}

The ISME Journal (2011) 5, 692-703; doi:10.1038/ismej.2010.157; published online 25 November 2010

Subject Category: geomicrobiology and microbial contributions to geochemical cycles

Keywords: geomicrobiology; deep biosphere; oceanic crust; observatory; hydrothermal

\section{Introduction}

Knowledge about life in the marine sedimentary deep biosphere has increased considerably in the last decade, leading to a better understanding of the distribution of microorganisms in global sediments (Parkes et al., 1994; D’Hondt et al., 2004; Inagaki et al., 2006), although many questions remain regarding the functioning of these microbial communities and their impacts on global chemical cycles. In contrast, the existence and functioning of a deep biosphere within exposed and deep oceanic crust is largely unknown and unconstrained. Oceanic crust comprises a vast and hydrologically

Correspondence: KJ Edwards, Department of Biology, University of Southern California, 3616 trousdale pkwy, LA 90089, USA.

E-mail: kje@usc.edu

${ }^{7}$ Current address: Center for Geomicrobiology, Aarhus University, DK-8000, Aarhus C, Denmark.

Received 19 April 2010; revised 2 August 2010; accepted 2 August 2010; published online 25 November 2010 active potential habitat for microbial life. Although some oceanic crust is buried by thick sediment, large areas of the seafloor are characterized by exposed oceanic crust, and these exposures serve as the conduits of exchange for fluids, heat, solutes and biological materials between the ocean and the lithosphere (Fisher and Wheat, 2010). Circulation of fluid within oceanic crust and redox reactions are known to occur in crust $<100 \mathrm{Ma}$ in age (Bach and Edwards, 2003). The rate at which water flows into and out of oceanic crust rivals the flow of all of the world's rivers, and most of this flow occurs at lowto-moderate temperatures $\left(0-40^{\circ} \mathrm{C}\right)$ on ridge flanks (Wheat et al., 2003). Considering that the circulating fluids are not in thermodynamic equilibrium with chemically-reduced basalts of the oceanic crust, life in the oceanic crust could be supported by lithotrophic reactions (Bach and Edwards, 2003; Edwards et al., 2005).

Little is currently known about microbial communities that reside in oceanic crust. Surveys of 
seafloor-exposed and buried basaltic crust (Lysnes et al., 2004; Mason et al., 2008; Santelli et al., 2008, 2009) and warm, near-surface fluids emanating from oceanic crust (Huber et al., 2006) indicate microbial communities numerically dominated by a diverse assemblage of Bacteria, in particular the Proteobacteria. However, the functioning of the various bacterial members of these communities is poorly understood, as is knowledge of the presence and behavior of Archaea or microbial eukaryotes. A profound challenge in investigating the crustal deep biosphere is avoiding the confounding influence of contamination during sampling, drilling and experiments (Lever et al., 2006; Santelli et al., 2010). Microbial communities are likely enriched where the crust is most permeable-the same areas that are the most susceptible to contamination by drilling because of the introduction of surface ocean water (used as drilling fluid), pipe lubricants, mud and other materials. One promising approach to overcome potential microbial contamination during drilling is through the use of subsurface observatory systems, known as CORKs ('Circulation Obviation Retrofit Kit'; Davis et al., 1992; Becker and Davis, 2005), where a borehole is cased and depths of interest are isolated and sealed, allowing the system to recover (thermally, chemically and microbiologically). Initial observatory systems addressed questions primarily concerning geophysics, hydrogeology and chemical composition and did not prioritize limiting potential sources of contamination for microbiological studies; however, in recent years, multidisciplinary teams that include microbiologists have focused on design and use of these systems to reduce contamination (Cowen et al., 2003; Jannasch et al., 2004; Fisher et al., 2005; Orcutt et al., 2010).

This study presents the first results from subsurface microbial colonization experiments within CORK observatories, demonstrating how these experiments can be used to capture in situ microorganisms and microbiological processes in ocean crustal settings.

\section{Materials and methods}

Observatory design, installation and recovery

Novel microbial colonization experiments were deployed within subseafloor borehole observatories on the eastern flank of the Juan de Fuca Ridge during Integrated Ocean Drilling Program Expedition 301 (Fisher et al., 2005), to examine crustal microbial communities in situ within young (3.5 Ma) oceanic crust. Two boreholes were targeted for investigation in this study (Supplementary Figure 1): Ocean Drilling Program Hole 1026B and Integrated Ocean Drilling Program Hole U1301A, separated by $1 \mathrm{~km}$ and located $\sim 6 \mathrm{~km}$ north of Baby Bare outcrop, a site where warm $\left(\sim 64^{\circ} \mathrm{C}\right)$ altered basement fluids discharge at the seafloor (Wheat and
Mottl, 2000; Wheat et al., 2000). The concept for these microbial experiments builds on the successful microbial colonization of mineral surfaces in the deep sea (Edwards et al., 2003; Toner et al., 2009; Orcutt et al., 2010). Each experiment consisted of a polycarbonate plastic hanger onto which four plastic grids were mounted with polycarbonate screws (Figure 1d). Each grid contained four polished rock chips $\left(\sim 1 \mathrm{~cm}^{2}\right)$ as colonization surfaces: one each of basalt, harzburgite (peridotite with high olivine content), pyrite/hematite and sheets of biotite. Experiment hangers were wrapped in aluminum foil, autoclaved for sterilization and stored sterile until inclusion on the CORK instrument strings that also contained fluid samplers and temperature loggers (Jannasch et al., 2004; Fisher et al., 2005; see Supplementary Materials), which were assembled in 2004 aboard R/V JOIDES Resolution. The subsurface experiment at Hole 1026B was deployed at a depth of 210 meters below seafloor, and the subsurface experiment at Hole U1301A was deployed at 280 meters below seafloor, $\sim 18 \mathrm{~m}$ below the sediment/basement interface. Notably, the CORK at Hole U1301A did not seal properly when installed (Fisher et al., 2005, 2008), and thus fluid exchange was possible between the seafloor and the lower borehole, with the direction of flow dependent on pressure (temperature) conditions within the borehole relative to that in the surrounding formation. Seawater flowed into the formation when the borehole was cold and contained excess fluid pressure, and formation fluid vented from the CORK at the seafloor when the borehole was warm and contained fluids at a pressure less than that in the surrounding formation. Instrument strings were recovered from the borehole observatories in August 2008 aboard the R/V Atlantis (cruise AT15-35) with the assistance of DSV Alvin (Woods Hole Oceanographic Institution; see Supplementary Materials for detailed recovery procedures).

Samples of borehole fluids from Holes 1026B and U1301A were collected using OsmoSamplers that were deployed directly below the microbial observatories (Jannasch et al., 2004; Fisher et al., 2005; Wheat et al., 2010). Temperature loggers were also deployed in tandem with these instruments. Complete information regarding the collection and analysis of these samples and loggers are available elsewhere (Figure 2; Wheat et al., 2010).

\section{Cell and particle imaging with confocal} epifluorescence, scanning electron microscopy (SEM) and micro-X-ray absorption spectroscopy

Particles and cells on the surfaces of the incubated chips were observed through a combination of staining, epifluorescence microscopy and SEM, with slight modification to protocols described previously (Edwards et al., 2003; see Supplementary Materials). Separate chip fragments that had not 
694
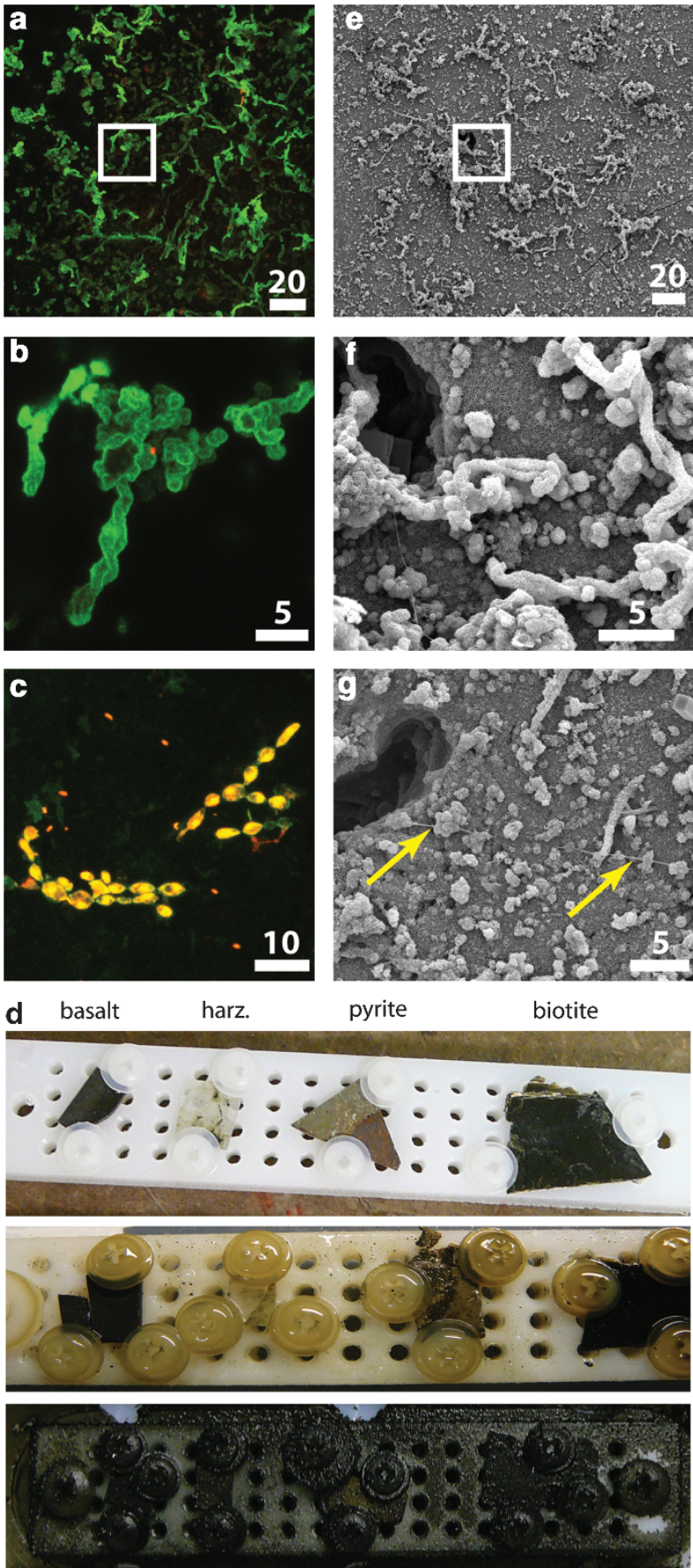

Figure 1 Conspicuous twisted-stalk particles (a, b, e, f, g) and cells (c) observed on the surfaces of the incubated rock chips from Hole U1301A (d), as imaged by epifluorescent confocal microscopy (a-c) and scanning-electron microscopy (e-g). Panels b and $\mathbf{f}$ are enlargements of the areas marked in (a) and (e), respectively. Panel d illustrates how the observatory device looked before (top row) and after (middle: Hole U1301A; bottom: Hole 1026B) 4 years of incubation, with each device containing four polished rock chips of basalt, harzburgite (harz.), pyrite/hematite (pyrite) and biotite. Fragments of the rock chips in (a-c) were dual stained with SYBR Green I (green) and propidium iodide (red; dual staining of cells appears orange/yellow); stalk particles appear green because of attachment of SYBR Green I stain to an unknown substance on stalks. The 'chain of bulbous cocci' cell morphology seen in panel $\mathbf{c}$ is also evident following dehydration for SEM. (g; chain marked by yellow arrows). The color reproduction of this figure is available on the html full text version of the manuscript. been stained were also evaluated to check for autofluorescence of minerals or other compounds. In addition, some of the plastic materials (that is, plastic screws holding the chips to the grids) from the observatory grids were checked with microscopy to evaluate if particles had also formed on their surfaces. Finally, samples of pipe dope used for CORK drill collar and pipe installation $60 \%$ Lead Base and ZN50 products, Bestolife Corporation (Dallas, TX, USA) were also checked for autofluorescence properties and potential interaction with fluorescent stains used in this study. Fluorescence images were collected on an inverted stage Leica TCS SPE confocal microscope using $488 \mathrm{~nm}$ (blue light excitation for the SYBR Green I dye) and $532 \mathrm{~nm}$ (green light excitation for the propidium iodide dye) wavelength lasers at $20 \%$ power with $63 \mathrm{X}$ oil objective magnification. Following confocal imaging, chip fragments were removed from the glass coverslips, cleaned with ethanol and prepared for SEM analysis (see Supplementary Materials). Additionally, scrapings of the mineral crusts from the Hole 1026B and Hole U1301A experiments that had been frozen were used for mineralogical analysis by field-emission SEM using a Zeiss Supra 40 at the University of Bremen.

A fragment of the Hole U1301A pyrite/hematite chip was removed using sterile tools, dehydrated in $80 \%$ ethanol for $5 \mathrm{~min}$, dried, and then embedded in quick-set epoxy under vacuum to create a 'thin' section for micro-X-ray absorption spectroscopy analysis, similar in principle to methods described elsewhere (Toner et al., 2009). X-ray fluorescence elemental maps of areas of interest on the thin section were analyzed at the Advanced Light Source on the 10.3.2 beamline (Marcus et al., 2004). Regions within and below the surface of the chip were then analyzed for $\mathrm{Fe}$ - and $\mathrm{Mn}$-X-ray absorption nearedge structure spectroscopy in fluorescence and transmission modes simultaneously at the K-edge (method details in Supplementary Materials).

\section{$16 S$ ribosomal RNA (rRNA) gene-based phylogeny}

Environmental DNA was extracted from 50-100 mg $\left(\sim 4 \mathrm{~mm}^{2}\right)$ frozen rock chip fragments, and from one of the plastic washers from the Hole U1301A experiment, for analysis of the microbial community based on the 16S rRNA gene following published protocols (Ausbel et al., 1999) utilizing cetrimonium bromide/phenol-chloroform extraction. Bacterial $16 \mathrm{~S}$ rRNA gene clone libraries were developed from both original environmental DNA extract and from multiple displacement amplification DNA product using the GenomiPhi kit, whereas archaeal 16S rRNA gene clone libraries were created from REPLI-g amplified DNA (see Supplementary Materials for method details). A negative control (that is, no sample added to DNA extraction buffers) was also run through all of the extraction, amplification and cloning procedures. 16S rRNA gene sequences from 


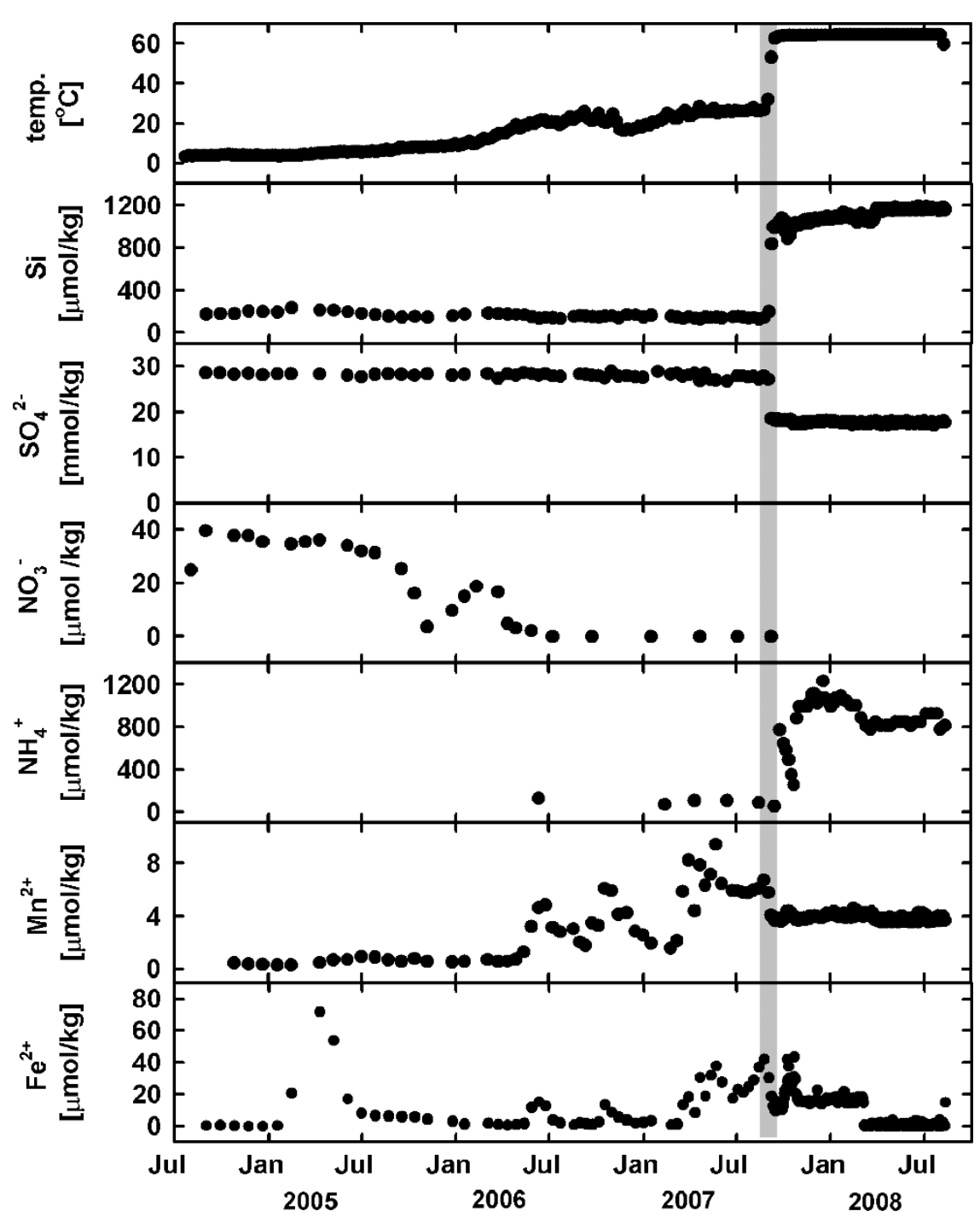

Figure 2 Records of temperature and chemical composition of borehole fluids from Hole U1301A document the history of rebound of the CORK borehole system to in situ conditions post-installation; final turn-around is marked by a gray vertical bar in all panels. $x$-axis for all panels are the same as listed for the lowest panel (modified from Wheat et al., 2010).

this study were submitted to Genbank under accession numbers GU188991-GU189038 and HM635226HM635263.

Thermodynamic modeling of potential reactions To evaluate the thermodynamic potential of various redox reactions within the observatory environment, water-rock path models were calculated (using Geochemist's workbench; Bethke, 1996), assuming heating from $2-65^{\circ} \mathrm{C}$ and the reaction of $30 \mathrm{~g}$ of basalt with $1 \mathrm{~kg}$ of seawater (see Supplementary Materials for further details). The available free energy was calculated for a range of redox reactions using the following equation:

$$
\Delta_{\mathrm{r}} \mathrm{G}=\Delta_{\mathrm{r}} \mathrm{G}^{\mathrm{o}}+R T \ln Q,
$$

where $\Delta_{\mathrm{r}} \mathrm{G}$ is the Gibb's energy of the reaction $\left(\mathrm{kJ} \mathrm{mol}^{-1} \mathrm{e}^{-}\right), \Delta_{\mathrm{r}} \mathrm{G}^{\circ}$ is the standard Gibbs energy yield of the same reaction at standard state $(250 \mathrm{bar}$, $2{ }^{\circ} \mathrm{C}<\mathrm{T}<65^{\circ} \mathrm{C}$, molal activities of solutes, unit activity of solids), $R$ is the universal gas constant, $T$ is the Kelvin temperature and $Q$ is the activity quotient, which is a function of the reactants and products. Reactions with negative values have available Gibbs energy to fuel potential microbial metabolic activity.

\section{Results}

Thermal and chemical development of the boreholes Experimental results are reported from both observatory sites, with emphasis on results from Hole U1301A, which document the dynamic response of borehole microbial communities to return towards natural environmental conditions following initial drilling- and observatory installation-related 
disturbances. In contrast, Hole 1026B produced reduced fluids throughout the deployment. All experimental components recovered from Hole 1026B were visibly coated in crusts of dark green/ black precipitate, whereas the Hole U1301A components were minimally altered by eye, although microscopic inspection revealed thin secondary mineralized biofilms (Figure 1d).

Temperature and fluid chemical data from these CORKs have been published elsewhere (Wheat et al., 2010); salient features are presented here for context. Temperature loggers and OsmoSamplers from the Hole U1301A CORK record a complex evolution of the post-installation borehole environment (Figure 2). For roughly 1 year following the installation of the CORK, the borehole had thermal and chemical profiles similar to that of seawater (that is, low temperatures, high sulfate concentrations and low silica concentrations), indicating that the formation had not returned to post-drilling conditions. Nitrate concentrations gradually decreased from seawater values at installation until being consumed by mid-2006. Starting in mid-2006, the borehole fluid temperature began to increase, hovering around $30^{\circ} \mathrm{C}$ until early September 2007 . During this time interval, some chemical constituents such as silica and sulfate did not change appreciably, suggesting that the borehole still contained seawater that was now gaining heat. During this warming phase, spikes were observed in manganese and iron concentrations, possibly reflecting the effect of corrosion of the lowalloy steel used in the CORK casing. In early September 2007, borehole fluids dramatically increased in temperature to $\sim 64{ }^{\circ} \mathrm{C}$, which corresponded with pronounced increases in silica and ammonium concentrations and a decrease in sulfate concentrations. Temperature, silica and sulfate concentrations were steady until recovery of the instrument string in August 2008. During this period, the composition of the borehole fluid closely resembled that of pre-drilling formation conditions. Manganese concentrations leveled off around $4 \mu \mathrm{mol} \mathrm{kg}{ }^{-1}$, although iron concentrations remained relatively elevated.

\section{Cells and particles on rock chip surfaces}

Epifluorescence microscopy and SEM of the reacted mineral surfaces in the Hole U1301A colonization experiment revealed cells (Figure 1c), twisted mineral particles (stalks; Figures $1 \mathrm{a}, \mathrm{b}$, e and f; Supplementary Figure 2a-c) and secondary mineral encrustation (that is, Mn phases; Figure 1f; Supplementary Figure 2a-c). The observed twisted stalks are morphologically similar to those reported from similar mineral colonization experiments conducted on the Juan de Fuca Ridge axis (Edwards et al., 2003; Toner et al., 2009; Supplementary Figure 2d, e), resembling stalks produced by microaerophilic, neutrophilic and iron-oxidizing bacteria (for exam- ple, Mariprofundus ferooxydans; Emerson et al., 2007) within iron oxide mats from oceanic hydrothermal vents (Emerson and Moyer, 2002; Supplementary Figure 2f). The pyrite chip, relative to the other three minerals, was the most covered by these stalk particles $(64 \pm 4 \%$ of surface area covered with stalks), followed by the basalt chip (20 $\pm 5 \%$ ), with the least coverage on the dunite $(13 \pm 5 \%)$ and biotite $(9 \pm 4 \%)$ chips. Notably, brightly stained cells were not observed at the ends of these stalk particles, indicating a lack of activity of the stalkforming microorganisms at the time of collection (Figure 1b). A common cell morphology observed on all chip surfaces was a string of bulbous ovoidshaped cells that average $\sim 3 \mu \mathrm{m}$ in length on the long axis (Figure 1c). Following dehydration for SEM, this string morphology was still evident, seen as collapsed nodes along a fiber (highlighted with arrows in Figure 1g). Smaller individual cocci cells were also observed (Figure 1c). Neither cells nor stalk particles were observed on the plastic components of the colonization experiment.

Secondary encrustation and alteration of the stalk particles and chip surfaces was obvious at multiple spatial scales from epifluorescence microscopy, SEM and X-ray fluorescence mapping. SEM analysis revealed microcrystalline features on the chip and stalks (Supplementary Figure 2a,b) and secondary alteration features coating the stalks and mineral surfaces (Supplementary Figure 3). Mineral crusts analyzed by SEM from the Hole 1026B observatory materials were dominated by jasper- (botryoidal Fe-Si oxide) and metal ( $\mathrm{Fe}, \mathrm{Cu}$, and $\mathrm{Zn}$ ) sulfideencrusted aragonite $\left(\mathrm{CaCO}_{3}\right)$ prisms (Supplementary Figure 3), which is consistent with the constant warm, reducing conditions exhibited in that hole during the entire experimental period (Wheat et al., 2010) that allowed extensive mineralization to occur. Mineral crusts from the Hole U1301A observatory materials also contained botryoidal $\mathrm{Fe}-\mathrm{Si}$ oxide, as well as pyrite encrustations exhibiting a range of morphologies from amorphous (not shown) to framboidal (Supplementary Figure 3a, b). Iron oxides were also observed on the Hole U1301A mineral crusts, although aragonite was not observed. X-ray fluorescence mapping of a cross-section through the pyrite/hematite chip fragment demonstrated that the upper surface of the chip was manganese-rich (Figure 3). Comparison with reference Mn K-edge X-ray absorption near-edge structure spectra indicated the Mn-containing mineral was a reduced $\mathrm{Mn}$ (II) phase. Underneath this top mineral crust were iron-rich particles (that is, the twisted stalks) that spectrally resembled Fe K-edge X-ray absorption near-edge structure spectra from Fe(III) oxyhydroxides such as goethite and two-line ferrihydrite. The presence of a goethite phase, which was confirmed by micro-X-ray diffraction patterns (data not shown), contrasts with the short-range ordered Fe(III) oxyhydroxides observed in young twisted stalks formed on seafloor-exposed mineral 


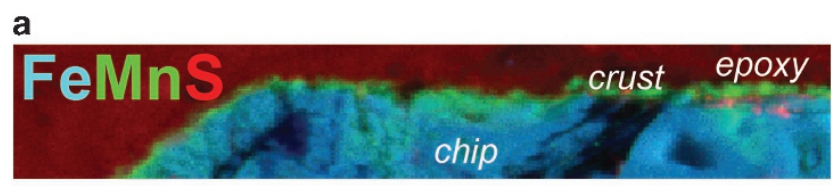

b

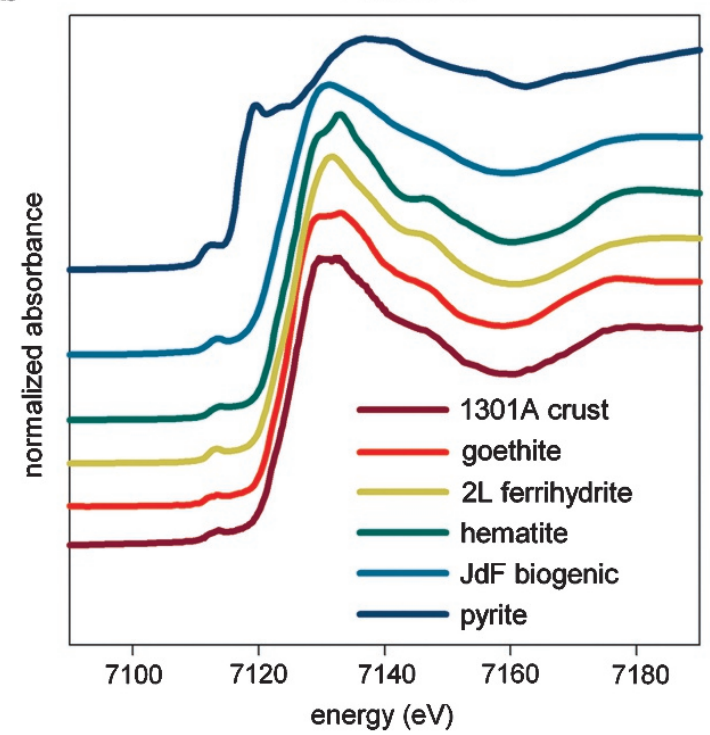

C

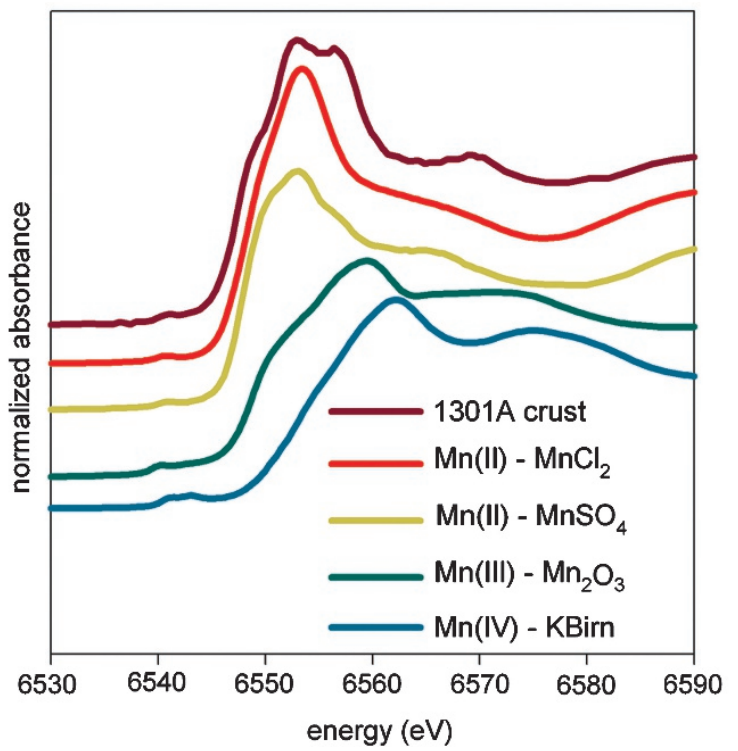

Figure 3 MicroXAS analysis of cross-section through reacted pyrite/hematite chip from Hole U1301A experiment. (a) XRF elemental map-with $\mathrm{Fe}$ in blue, $\mathrm{Mn}$ in green and $\mathrm{S}$ in redrevealing a Mn-rich crust coating the upper surface of the Fe-rich chip. (b) Fe K-edge XANES spectra of the Hole U1301A crust in comparison with reference standards (where 'JdF biogenic' refers to the material described in Toner et al., 2009), indicating that the particles underneath the crust have an iron oxyhydroxide signature. (c) Mn K-edge XANES of the Hole U1301A crust in comparison with reference standards, indicating that the $\mathrm{Mn}$ in the crust is in the form of Mn(II). Note $y$-axis in panels (b) and (c) depict normalized absorbance on an arbitrary scale. The color reproduction of this figure is available on the html full text version of the manuscript. surfaces at the Juan de Fuca Ridge (Toner et al., 2009). This suggests that there was recrystallization of the microbial Fe(III) oxyhydroxides, likely resulting from hydrothermally-driven alteration reactions with warm, reducing fluids.

Microbial 16S rRNA gene sequencing

DNA was successfully extracted and amplified from fragments of the basalt and pyrite chips from the Hole U1301A experiment, as well as from one of the plastic washers from this experiment. Bacterial 16S rRNA gene clones were obtained from PCR reactions with both the direct DNA extract and whole genome amplified DNA, with no strong bias in the types of sequences recovered from either method (that is, similar dominant phylotypes were recovered using both approaches; data not shown). On account of the limited sample size of the original DNA extract, archaeal 16S rRNA gene clones were only recovered from REPLI-g-amplified DNA extract. Cloning was unsuccessful from the Hole 1026B rock chip fragments-either the straight DNA extract or GenomiPhi-amplified extract yielded PCR products that were suitable for cloning.

A majority $(52 \%, 45$ out of 87 sequences) of bacterial sequences from the Hole U1301A subsurface experiments grouped with the Firmicutes phyla (Figure 4). For many of these sequences, the closest relatives are environmental sequences recovered from Hole 1026B during previous studies of the CORK fluids (Cowen et al., 2003) and a black rust formed on the Hole 1026B CORK platform where it was in contact with venting formation fluids and bottom water (Nakagawa et al., 2006a). Many of these sequences were not closely related to cultivated microorganisms, although some of the sequences $(10 \%)$ were closely related to an anaerobic, thermophilic isolate cultivated from Hole 1026B (Huber et al., 2006) and to Caloranaerobacter azorensis, an anaerobic, thermophilic chemo -organotroph isolated from a Mid-Atlantic Ridge hydrothermal chimney (Wery et al., 2001). Other close environmental sequence relatives included environmental sequences from terrestrial subsurface mine waters (Gihring et al., 2008) and from a hightemperature marine oil-reservoir service waters (Gittel et al., 2009).

The second most prevalent bacterial phylogenetic group of the Hole U1301A subsurface experiment sequences was within the OP8 clade $(13 \%$ of sequences; Supplementary Figure 4), a candidate phylum that does not contain cultivated members. Within this clade, the Hole U1301A sequences grouped most closely to other environmental sequences from marine sediments (Teske et al., 2002; Bowman and McCuiag, 2003; Parkes et al., 2005) and crustal fluids (Huber et al., 2006). A few sequences from this study grouped within the Proteobacteria (Supplementary Figure 4), some showing closest sequence similarity to other environmental sequences from Juan de Fuca 


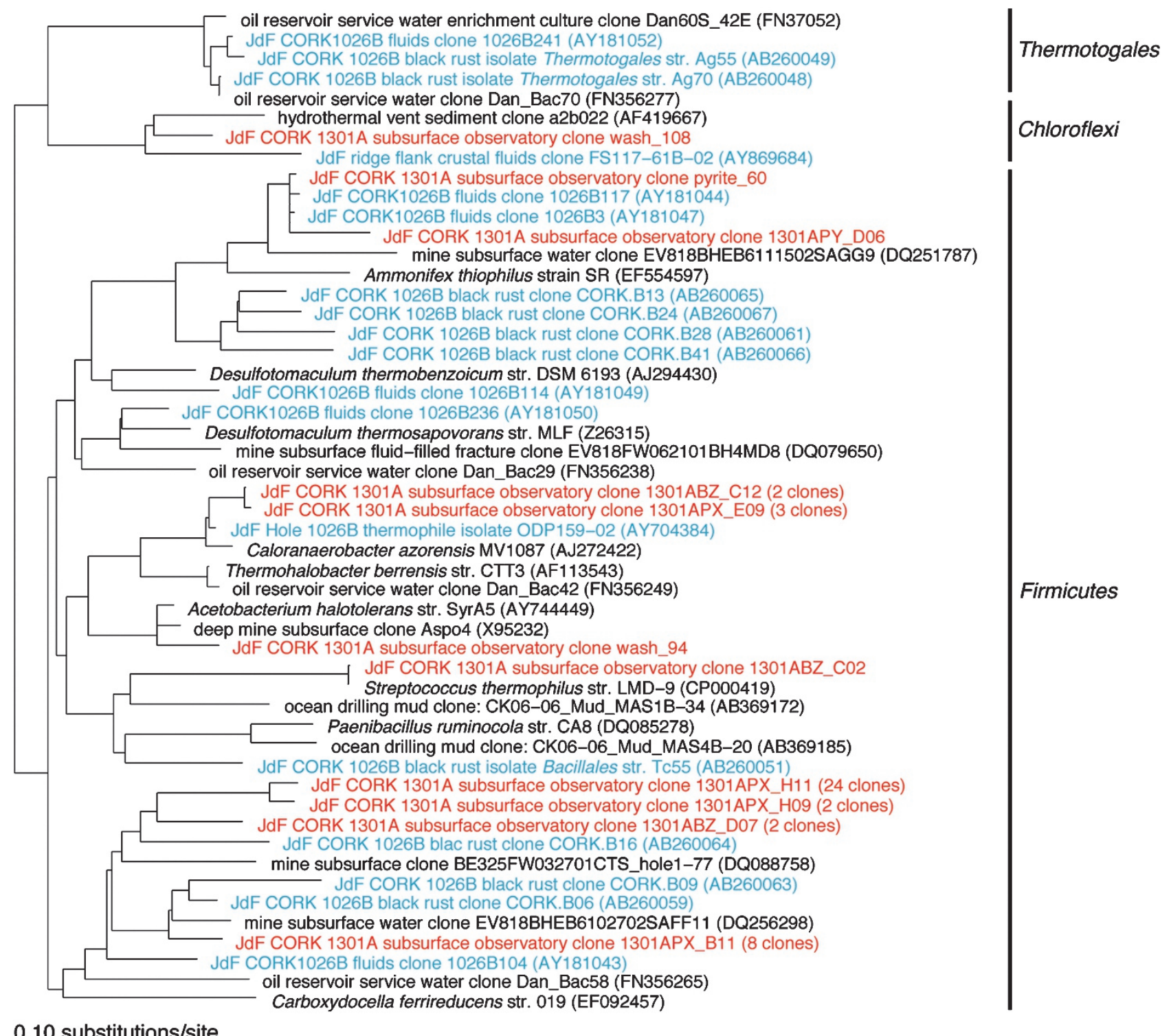

\subsection{0 substitutions/site}

Figure 4 Phylogenetic tree of subset of bacterial 16S rRNA gene sequences (Firmicutes and Thermotogae phyla) from Hole U1301A colonized rock chips. Sequences from this investigation in red, sequences from Hole 1026B black rust (Nakagawa et al., 2006a) and fluid (Cowen et al., 2003) in blue; and isolates in italics. The color reproduction of this figure is available on the html full text version of the manuscript.

ridge flank crustal fluids (Huber et al., 2006). Four sequences grouped relatively closely to environmental clones from marine basalts (Santelli et al., 2008) and granite mines (Sahl et al., 2008) that are related to the cultivated aerobic microorganism Stenotrophomonas maltophila, a known human pathogen that is also prevalent in aqueous environments. One sequence grouped near the Desulfonatronum and Desulftonatronovibrio genera, known to be heterotrophic and autotrophic, alkaliphilic, sulfate-reducing bacteria that can use hydrogen and formate and electron sources. Three sequences grouped closely to Alpha-proteobacteria and Verrucomicrobia microorganisms cultivated from the marine water column.
The archaeal communities observed on the Hole U1301A subsurface experiment had low diversity (Figure 5) with membership from only four groups of archaea. Two sequences grouped closely with cultivated species of the Methanosarcina, which are known as methanogenic euryarchaeota. Seven archaeal sequences grouped within the Archaeaoglobus clade, members of which are commonly recovered from hydrothermal environments and deep marine-oil production (Gittel et al., 2009). Four sequences grouped within the SAGMA-G clade of uncultivated crenarchaeota often found in terrestrial subsurface mines, and one sequence grouped with the uncultivated miscellaneous crenarchaeota group commonly found in deep marine sediments. 


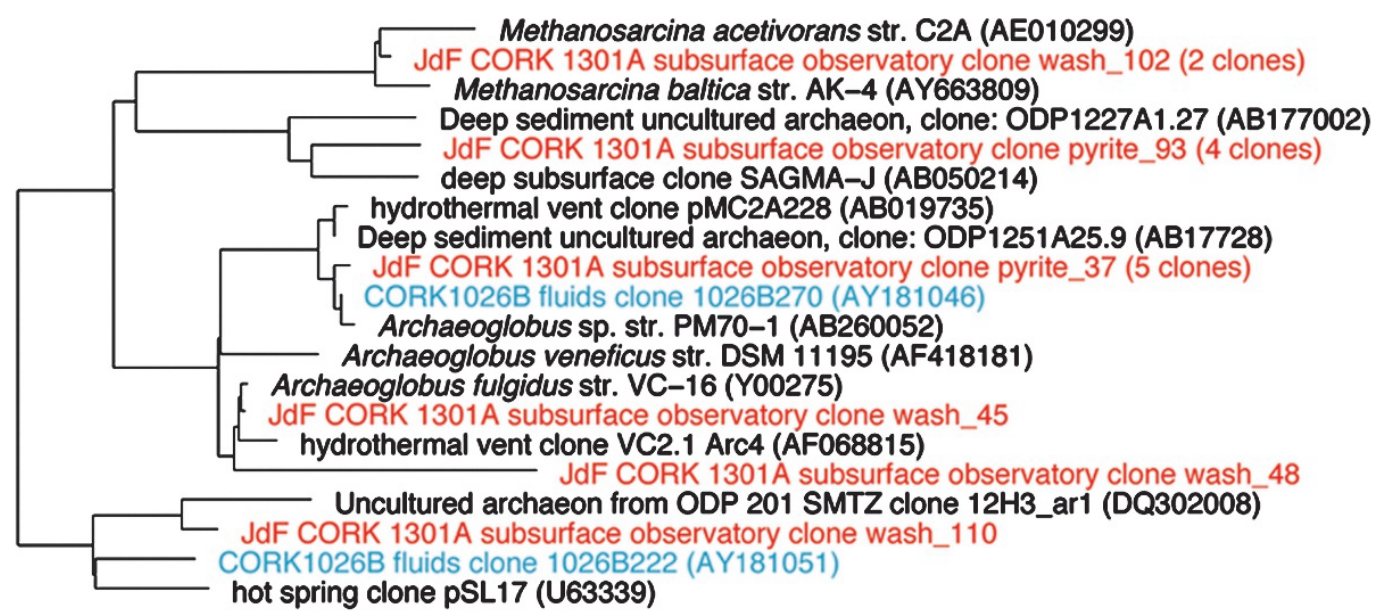

Methanosarcina

SAGMA

Archaeoglobus

Archaeoglobus fulgidus str. VC-16 (Y00275)

dF CORK $1301 \mathrm{~A}$ subsurface observatory clone wash_45

AF068815)

CORK 1301A subsurface observatory clone wash 48

JdF CORK 1301A subsurface observatory clone wash 110

hot spring clone pSL17 (U63339)

\subsection{0 substitutions/site}

Figure 5 Phylogenetic tree of archaeal 16S rRNA gene sequences from Hole U1301A colonized rock chips. Same conditions as specified in Figure 4. The color reproduction of this figure is available on the html full text version of the manuscript.

a

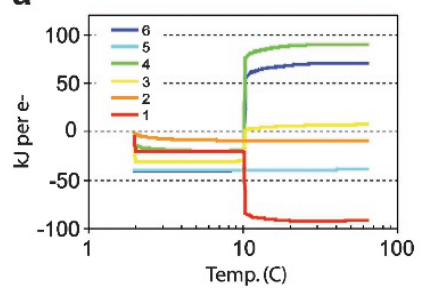

b

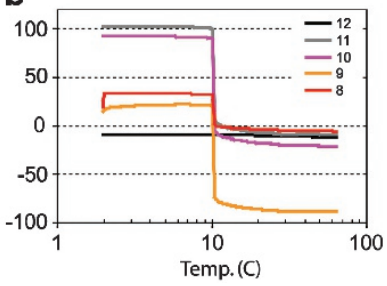

Figure 6 Gibbs energy yields of reactions (in $\mathrm{kJ} \mathrm{mol}^{-1} \mathrm{e}^{-}$) calculated from a rock-seawater reaction model at temperatures ranging from $2-65^{\circ} \mathrm{C}$. Note logarithmic temperature axis in both panels. (a) Oxidation reactions (1-6) of $\mathrm{Fe}(\mathrm{II}), \mathrm{Mn}$ (II) and $\mathrm{NH}_{4}^{+}$ with oxygen and nitrate. (b) Reduction reactions (8-12) of Fe(III), $\mathrm{Mn}(\mathrm{IV}), \mathrm{SO}_{4}^{2-}$, and $\mathrm{HCO}_{3}^{-}$with $\mathrm{H}_{2}$, and anaerobic methane oxidation with sulfate. Reactions considered include 1: $5 \mathrm{Fe}^{2+}+$ $\mathrm{NO}_{3}^{-}+7 \mathrm{H}_{2} \mathrm{O} \rightarrow 5 \mathrm{FeOOH}+0.5 \mathrm{~N}_{2}+9 \mathrm{H}+; 2: 5 \mathrm{Mn}^{2+}+2 \mathrm{NO}_{3}^{-}+4 \mathrm{H}_{2} \mathrm{O} \rightarrow$ $5 \mathrm{MnO}_{2}+\mathrm{N}_{2}+8 \mathrm{H}^{+} ; 3: \mathrm{Fe}^{2+}+0.25 \mathrm{O}_{2}+1.5 \mathrm{H}_{2} \mathrm{O} \rightarrow \mathrm{FeOOH}+2 \mathrm{H}^{+} ; 4:$ $\mathrm{Mn}^{2+}+0.5 \mathrm{O}_{2}+\mathrm{H}_{2} \mathrm{O} \rightarrow \mathrm{MnO}_{2}+2 \mathrm{H}^{+}: \quad 5: \quad 3 \mathrm{NO}_{3}^{-}+5 \mathrm{NH}_{4}^{+} \rightarrow 4 \mathrm{~N}_{2}+$ $9 \mathrm{H}_{2} \mathrm{O}+2 \mathrm{H}^{+} ; \quad 6: \quad \mathrm{NH}_{4}^{+}+2 \mathrm{O}_{2} \rightarrow \mathrm{NO}_{3}^{-}+2 \mathrm{H}^{+}+\mathrm{H}_{2} \mathrm{O} ; \quad$ 8: $\mathrm{FeOOH}+$ $0.5 \mathrm{H}_{2}+2 \mathrm{H}^{+} \rightarrow \mathrm{Fe}^{2+}+2 \mathrm{H}_{2} \mathrm{O} ; \quad 9: \quad \mathrm{MnO}_{2}+\mathrm{H}_{2}+2 \mathrm{H}^{+} \rightarrow \mathrm{Mn}^{2+}+2 \mathrm{H}_{2} \mathrm{O}$; 10: $\quad \mathrm{SO}_{4}^{2-}+4 \mathrm{H}_{2}+2 \mathrm{H}^{+} \rightarrow \mathrm{H}_{2} \mathrm{~S}+4 \mathrm{H}_{2} \mathrm{O} ; \quad$ 11: $\quad \mathrm{HCO}_{3}^{-}+4 \mathrm{H}_{2}+\mathrm{H}^{+} \rightarrow$ $\mathrm{CH}_{4}+3 \mathrm{H}_{2} \mathrm{O} ; 12: \mathrm{SO}_{4}^{2-}+\mathrm{CH}_{4}+\mathrm{H}^{+} \rightarrow \mathrm{H}_{2} \mathrm{~S}+\mathrm{HCO}_{3}^{-}+\mathrm{H}_{2} \mathrm{O}$. The color reproduction of this figure is available on the html full text version of the manuscript.

\section{Thermodynamic calculations}

Results from the equilibrium rock-water reaction calculations indicate that $\mathrm{Fe}(\mathrm{II})$ oxidation with oxygen would be favorable (that is, negative $\Delta_{\mathrm{r}} G$ ) during the cooler periods of the experiment, such as when seawater was flowing into Hole U1301A, becoming unfavorable as temperatures increased in September 2007 (Figure 6). The switch to unfavorable conditions is related to the removal of oxygen from the reaction environment. The oxidation of $\mathrm{Mn}(\mathrm{II})$ and $\mathrm{NH}_{4}^{+}$with oxygen also change from thermodynamically favorable to unfavorable as temperature increases. The temperature of the transition from favorable to unfavorable conditions

is dependent on the quantity of rock considered to have reacted in the model, with a greater waterto-rock ratio resulting in a lower temperature for the transition (data not shown). By contrast, Fe(II), $\mathrm{Mn}(\mathrm{II})$ and $\mathrm{NH}_{4}^{+}$oxidation with nitrate are thermodynamically favorable at all of the temperatures considered. Reduction reactions involving hydrogen-reducing iron oxyhydroxides, manganese oxide, sulfate and bicarbonate only become thermodynamically favorable at the warmer temperatures and in a reducing, anaerobic environment. These results indicate that iron oxidation would have been a possible reaction in the early, cooler periods of the observatory experiment (Figure 2).

\section{Discussion}

Results presented here offer the first evidence for the potential of subsurface microbial observatories to capture in situ microorganisms and processes in ocean crustal settings. Notably, the colonization experiments recovered from Hole U1301A recorded a dynamic microbial community responding to environmental conditions within the crustal borehole environment. These studies emphasize the transient nature of microbial communities and highlight the need for time-series observations and analyses to interpret the microbiological influence on mineralogical processes.

During the first year of the deployment at Hole U1301A, thermal and chemical conditions within the borehole indicate a strong seawater influence (Figure 2; Wheat et al., 2010). Surface seawater is pumped into crustal boreholes during drilling for lubrication of the drill-bit and to remove borehole cuttings, and additional bottom seawater water flows in these holes because of the higher 
hydrostatic pressure of cold seawater fluids in the borehole relative to ambient formation conditions (Fisher and Wheat, 2010). Incomplete sealing of the Hole U1301A borehole observatory at the seafloor allowed the flow of cold bottom water to continue for several years (Fisher et al., 2008). The borehole fluid warmed over time (Figure 2), and eventually the natural-formation fluid overpressure overcame the excess pressure of the cold seawater in the borehole, resulting in producing borehole in which formation fluids within the crust flowed into and up the borehole, discharging at the seafloor. Borehole conditions rebounded towards a thermal $\left(\sim 64{ }^{\circ} \mathrm{C}\right)$ and chemical state (Figure 2), consistent with regional basement conditions (Wheat et al., 2004) as observed at Baby Bare outcrop (Wheat and Mottl, 2000; Wheat et al., 2000) where there is no perturbation associated with a borehole observatory emplacement or recovery. Before the rebound, nitrate concentrations decreased and showed nonconservative mixing behavior relative to other ions such as Mg, suggestive of microbial consumption (Wheat et al., 2010). Oxygen was likely present in borehole fluids when nitrate concentrations were at bottom seawater values and we infer that it also became depleted during the period of nitrate consumption, although no record of oxygen concentration is available. Nitrate and oxygen serve as electron acceptors in redox reactions involving iron, which also was present in the borehole fluids, likely because of the reaction of the low-alloy steel pipe used for observatory construction.

In combination with available chemical and temperature data (Figure 2; Wheat et al., 2010), the results presented herein indicate that the Hole U1301A experiments recorded early colonization by iron oxidizing bacteria, followed by a shift in community structure when the borehole returned to reducing conditions. The twisted iron oxyhydroxides stalk particles observed on the rock chips (Figure 1, Supplementary Figure 2), exhibiting morphological similarity to seafloor mineral incubation experiments (Edwards et al., 2003), indicate colonization by iron oxidizing bacteria when conditions were thermodynamically favorable for this process (Figure 6). Notably, the density of the twisted-stalk particles was highest on the pyrite/ hematite chip, the most reactive mineral substrate (susceptibility to oxidation and dissolution) among those tested, indicating preferential colonization of that surface despite the probability that iron was present in borehole fluids at variable levels throughout the experimental period. Following the shift of borehole conditions towards a more natural reducing state, the loss of suitable electron acceptors thermodynamically disfavors iron oxidation (Figure 6); thus the microbial groups responsible for this process, and for forming the twisted-stalk particles, would have died out, leaving only the stalk particles as fossil evidence of their former presence. This interpretation is consistent with the absence of 16S rRNA gene sequences related to known stalk-forming iron-oxidizing bacteria (that is, zeta-proteobacteria such as Mariprofundus spp.; Emerson et al., 2007; Rassa et al., 2009) and the lack of cells at the ends of twisted stalks.

A second phase of mineral alteration is evidenced by a Mn(II)-rich crust on the pyrite chip surface, identified by coupled X-ray fluorescence mapping and X-ray absorption near-edge structure (Figure 3), alteration in the form of etching and pitting of twisted-stalk particles (Figure 1f, Supplementary Figure 2), and identification of higher order Fe(III) oxyhydroxide signatures of the stalks compared with 'fresher' biogenic stalk material (Toner et al., 2009). These data correlate well with the warm, reducing conditions in Hole U1301A following rebound (Figure 2). We infer that the incipient secondary mineralization on the Hole U1301A observatory materials (that is, reduced Mn mineralization) reflects an earlier stage of mineralization in reducing, warm borehole fluids by comparison with the more mature mineral products observed in the Hole 1026B experiment. This interpretation is consistent with microbiological evidence presented here and in other studies. Specifically, the contemporary microbial community associated with colonization materials deployed in Hole U1301A that were recovered after the hole rebounded (Figures 4,5, Supplementary Figure 4) exhibit significant phylogenetic similarity to microbial communities previously identified from Hole 1026B borehole fluids and black-rust formation at the producing well head (Cowen et al., 2003; Nakagawa et al., 2006a), which had experienced similar chemical and temperature conditions (Wheat et al., 2004). This overlap in community composition, especially considering the different protocols used in the various investigations, provides further validation that the previous phylogenetic results from Hole 1026B (Cowen et al., 2003; Nakagawa et al., 2006a) are indeed representative of in situ populations of microorganisms. Furthermore, sequences recovered from Hole U1301A did not group closely to environmental sequences obtained from ocean drilling muds (Masui et al., 2008), suggesting that the in situ microbial communities are not in-growths of drilling mud-related contaminants.

The contemporary Hole U1301A subsurface bacterial community was dominated by the Firmicutes phylum, phylogenetically grouping with microorganisms with unclear physiological function. Considering phylogenetic placement, some sequences grouped near Ammonifex genera (Figure 4), known as thermophilic, chemolithoautotrophs capable of growth utilizing hydrogen, formate or pyruvate coupled to nitrate, sulfate or $\mathrm{S}^{\circ}$ reduction. Cowen et al. (2003) speculate that the association of environmental clones to Ammonifex in Hole 1026B fluids might indicate nitrate reduction to ammonia with hydrogen as the electron donor, as is the case for some Ammonifex-related microorganisms, although ammonium may also be derived from 
sediment influence. The recent chemical record from Hole U1301A (Figure 2; Wheat et al., 2010) indicates that high ammonium levels correspond to hydrothermal alteration of sediments or drilling muds within the basaltic formation and are not attributable to a biological reaction. Nakagawa et al. (2006a) suggest that the Ammonifex-related microorganisms may be involved in sulfate reduction coupled to hydrogen oxidation, with hydrogen formation resulting from reactions between water and steel-observatory components. Given that the environmental sequences from this study and others are distantly related to cultivated species ( $\sim 90 \%$ sequence similarity), inference of physiology is likely tenuous and requires successful cultivation or other techniques (for example, activity measurements), as mentioned previously (Cowen et al., 2003). Some (10\%) of the sequences are related to an anaerobic, thermophilic isolate cultivated from Hole 1026B (Huber et al., 2006), and to Caloranaerobacter azorensis, an anaerobic, thermophilic chemo-organotroph isolated from a Mid-Atlantic Ridge hydrothermal chimney (Wery et al., 2001), further evidence that the Hole U1301A experiments were colonized by hydrothermal, basement-derived microbial communities. Environmental sequences from terrestrial subsurface mine waters (Gihring et al., 2008) also grouped with Hole U1301A sequences, suggesting a common deep-biosphere linkage between marine and terrestrial realms.

Although there are strong similarities between the contemporary Hole U1301A observatory community and Hole 1026B communities (Cowen et al., 2003; Nakagawa et al., 2006a), the overall phylogenetic composition of the Hole U1301A microbial community is strikingly different from those inhabiting seafloor-exposed (Santelli et al., 2008) and near-surface (Huber et al., 2006) basalts, inactive chimney sulfides (Suzuki et al., 2004; Toner et al., in review), and hydrothermal chimneys and fluids (Nakagawa et al., 2006b; Perner et al., 2007; Takai et al., 2008). Seafloor-exposed basalts and sulfides tend to harbor communities dominated by members of the $\alpha$ - and $\gamma$-Proteobacteria, whereas hydrothermal environments are often characterized by Epsilon-Proteobacteria and high proportions of Archaea. We suggest that the unique microbial communities of Holes 1026B (Cowen et al., 2003; Nakagawa et al., 2006a) and U1301A relate to in situ conditions of this crustal environment.

This unique dataset from the first colonization experiments to be deployed in long-term subseafloor observatories in young oceanic crust documents the dynamic nature of subsurface ocean crust microbial communities in association with changing fluid conditions-ecording early colonization by iron oxidizing bacteria, and later colonization by an anaerobic microbial community dominated by Firmicutes. This change took place over a few years in Hole U1301A, due to the nature of observatory installation and formation response. These results document and explain two major population shifts in a deep subseafloor habitat. This observation contrasts the current understanding of subsurface microbial populations as relatively stagnant, with long turnover times, as has been inferred in sedimentary deep-biosphere environments (Jørgensen and Boetius, 2007). Results demonstrated in this relatively short-term perturbation experiment are nonetheless representative of natural ridge-flank hydrothermal systems, which follow a similar trajectory in thermal and chemical conditions over centuries to millennia as they evolve from a more open and oxic state to a warmer, more isolated and more altered composition (Hutnak and Fisher, 2007; Wheat et al., 2010). These results emphasize the need for multi-faceted approaches for interpreting current and past processes, as the dynamics, history and succession in the borehole environment can only be interpreted against the backdrop of coupled mineralogical, microbiological, thermal and geochemical approaches (for example, 16S rRNA gene analysis alone would only reveal the contemporary community). The upper oceanic crust is the most voluminous, continuous aquifer system on the planet, yet we know little about what kinds of life this habitat may harbor, what strategies microorganisms employ to generate energy and acquire carbon, or how similar/different these microorganisms are to the deep ocean, deep sedimentary and continental realms. Our results and others (Orcutt et al., 2010) show how subseafloor microbial observatories can yield a more complete understanding of the function, activity, size and consequence of this biosphere, which will elucidate how microbial activity in the ocean crust may influence global biogeochemical cycles, crustal properties and related processes.

\section{Acknowledgements}

We acknowledge the assistance of S Fakra, M Marcus, S Bennett, and A Turner with synchrotron analysis at the Advanced Light Source, and A Thompson at the Center for Electron Microscopy and Micro-Analysis for assistance with SEM measurements, and $\mathrm{T}$ Thompsen for assistance with cloning. We also thank M Malone for providing samples of the pipe dopes. This work was supported by funding from the NSF Ocean Drilling Program (OCE-0737300 to KJE, OCE-0400471 to KB, OCE-0400462 to CGW and OCE-0727952 to AF), the Gordon and Betty Moore Foundation (No. 1609 to KJE and CGW), and the Office of the Vice President for Research, University of Minnesota (BMT). The Advanced Light Source is supported by the Office of Science, Basic Energy Sciences, Division of Materials Science of the US Department of Energy under contract No. DE-AC0205CH11231. 


\section{References}

Ausbel FM, Brent R, Kingston RE, Moore DD, Seidman JG, Smith JA et al. (1999). Short protocols in molecular biology, 4th edn. Wiley John \& Sons Inc Unit 2.4 .

Bach W, Edwards KJ. (2003). Iron and sulfide oxidation within the basaltic ocean crust: implications for chemolithoautotrophic microbial biomass production. Geochim Cosmochim Acta 20: 3871-3887.

Becker K, Davis EE. (2005). A review of CORK designs and operations during the ocean drilling program. In Fisher AT, Urabe T, Klaus A, (eds) and the Expedition 301 Scientists, Proc. IODP 301: College Station, TX. doi: 10.2204/iodp.proc.301.104.2005.

Bethke CM. (1996). Geochemical reaction modeling. Oxford University Press, New York, NY.

Bowman JP, McCuaig RD. (2003). Diversity, community structural shifts, and biogepgraphy of prokaryotes within Antarctic continental shelf sediment. Appl Environ Microbiol 69: 2463-2483.

Cowen JP, Giovannoni SJ, Kenig F, Johnson HP, Butterfield D, Rappe MS et al. (2003). Fluids from aging ocean crust that support microbial life. Science 299: 120-123.

Davis EE, Becker K, Pettigrew T, Carson B, MacDonald R. (1992). CORK: a hydrologic seal and downhole observatory for deep-ocean boreholes. Proc ODP Init Repts 139: 43-53.

D’Hondt S, Jørgensen BB, Miller DJ, Batzka A, Blake R, Cragg BA et al. (2004). Distributions of microbial activities in deep subseafloor sediments. Science 306: 2216-2221.

Edwards KJ, Bach W, McCollom TM. (2005). Geomicrobiology in oceanography: microbe-mineral interactions at and below the seafloor. Trends Microbio. 13: 449-456.

Edwards KJ, McCollom TM, Konishi H, Buseck PR. (2003). Seafloor bioalteration of sulfide minerals: Results from in situ incubation studies. Geochim Cosmochim Acta 67: 2843-2856.

Emerson D, Moyer CL. (2002). Neutrophilic Fe-oxidizing bacteria are abundant at the Loihi Seamount hydrothermal vents and play a major role in $\mathrm{Fe}$ oxide deposition. Appl Environ Microbiol 68: 3085-3093.

Emerson D, Rentz JA, Lilburn TG, Davis RE, Aldrich H, Chan C et al. (2007). A novel lineage of proteobacteria involved in formation of marine Fe-oxidizing microbial mat communities. PLOS ONE 8: e667.

Fisher AT, Davis EE, Becker K. (2008). Borehole-to-borehole hydrologic response across $2.4 \mathrm{~km}$ in the upper ocean crust: implications for crustal scale properties. J Geophys Res. 113, B07106, p 15.

Fisher AT, Wheat CG, Becker K, Davis EE, Jannasch H, Schroeder D et al. (2005). Scientific and technical design and deployment of long-term, subseafloor observatories for hydrogeologic and related experiments, IODP Expedition 301, eastern flank of Juan de Fuca Ridge. In Fisher AT, Urabe T, Klaus A, and the Expedition 301 Scientists, Proc. IODP. (Integrated Ocean Drilling Program Management International, Inc.), 301: College Station, TX, doi: 10. 2204/iodp. proc.301.103.2005.

Fisher AT, Wheat CG. (2010). Seamounts as conduits for massive fluid, heat, and solute fluxes on ridge flanks. Oceanography 23: 74-87.
Gihring TM, Moser DP, Lin L-H, Davidson M, Onstott TC, Morgan L et al. (2008). The distribution of microbial taxa in the subsurface warer of the Kalahari shield, South Africa. Geomicrobiol J 23: 415-430.

Gittel A, Sørensen KB, Skovhus TL, Ingvorsen K, Schramm A. (2009). Prokaryotic community structure and sulfate reducer activity in water from hightemperature oil reservoirs with and without nitrate treatment. Appli Environ Microbiol 75: 7086-7096.

Huber JA, Johnson HP, Butterfield DA, Baross JA. (2006). Microbial life in ridge flank crustal fluids. Environ Microbiol 8: 88-99.

Hutnak M, Fisher AT. (2007). The influence of sedimentation, local and regional hydrothermal circulation, and thermal rebound on measurements of seafloor heat flux. J Geophys Res 112: B12101.

Inagaki F, Nunoura T, Nakagawa S, Teske A, Lever M, Lauer A et al. (2006). Biogeographical distribution and diversity of microbes in methane hydrate-bearing deep marine sediments on the Pacific Ocean Margin. Proc Nat Acad Sci USA 103: 2815-2820.

Jannasch HW, Wheat CG, Plant JN, Kastner M, Stakes DS. (2004). Continuous chemical monitoring with osmotically pumped water samplers: OsmoSampler design and applications. Limnol Oceangr: Methods 2: 102-113.

Jørgensen J, Boetius A. (2007). Feast and famine - microbial life in the deep-sea bed. Nature Rev Microb 5: 770-781.

Lever MA, Alperin M, Engelen B, Inagaki F, Nakagawa S, Steinsbu BO, et al., IODP Expedition Scientists. (2006). Trends in basalt and sediment core contamination during IODP Expedition 301. Geomicrobiol J 23: 517-530.

Lysnes K, Thorseth IH, Steinsbu BO, vreas L, Torsvik T, Pedersen RP. (2004). Microbial community diversity in seafloor basalt from the Arctic spreading ridges. FEMS Microbiol Ecol 50: 213-230.

Marcus MA, MacDowell A, Celestre R, Manceau A, Miller T, Padmore HA et al. (2004). Beamline 10.3.2 at ALS: a hard X-ray microprobe for environmental and material sciences. J Synchrotron Rad 11: 239-247.

Mason OU, Di Meo-Savoie CA, Van Nostrand JD, Zhou J, Fisk MR, Giovannoni SJ. (2008). Prokaryotic diversity, distribution, and insights into their role in biogeochemical cycling in marine basalts. ISME $J \mathbf{3}$ : 231-242.

Masui N, Morono Y, Inagaki F. (2008). Microbiological assessment of circulation mud fluids during the first operation of riser drilling by the Deep-Earth research Vessel Chikyu. Geomicrob J 25: 274-282.

Nakagawa S, Inagaki F, Suzuki Y, Steinsbu BO, Lever MA, Takai K, Integrated Ocean Drilling Program Expedition 301 Scientists et al. (2006a). Microbial community in black rust exposed to hot ridge flank crustal fluids. Appl Environ. Microbiol 72: 6789-6799.

Nakagawa T, Takai K, Suzuki Y, Hirayama H, Konno U, Tsunogai U et al. (2006b). Geomicrobiological exploration and characterization of a novel deep-sea hydrothermal system at the TOTO caldera in the Mariana Volcanic Arc. Envirom Microb 8: 37-49.

Orcutt B, Wheat CG, Edwards KJ. (2010). Subseafloor ocean crust microbial observatories: development of FLOCS (FLow-through Osmo Colonization System) and evaluation of borehole construction materials. Geomicrobiol J 27: 143-157. 
Parkes RJ, Cragg BA, Bale SJ, Getliff JM, Goodman K, Rochelle PA et al. (1994). Deep bacterial biosphere in Pacific Ocean sediments. Nature 371: 410-413.

Parkes RJ, Webster G, Cragg BA, Weightman AJ, Newberry CJ, Ferdelman TG et al. (2005). Deep sub-seafloor prokaryotes stimulated at interfaces over geologic time. Nature 436: 390-394.

Perner M, Kuever J, Seifert R, Pape T, Koschinsky A, Schmidt K et al. (2007). The influence of ultramafic rocks on microbial communities at the Logatchev hydrothermal field, located $15^{\circ} \mathrm{N}$ on the Mid-Atlantic Ridge. FEMS Microbio Ecol 61: 97-109.

Rassa AC, McAllister SM, Safran SA, Moyer CL. (2009). Zeta-proteobacteria dominate the colonization and formation of microbial mats in low-temperature hydrothermal vents at Loihi Seamount, Hawaii. Geomicrob J 26: 623-638.

Sahl JW, Schmidt R, Swanner E, Mandernack K, Templeton A, Kieft $\mathrm{T}$ et al. (2008). Subsurface microbial diversity in deep-granitic-fracture water in Colorado. Appl Environ Microbiol 74: 143-152.

Santelli CM, Banerjee N, Bach W, Edwards KJ. (2010). Tapping the subsurface ocean crust biosphere: low biomass and drilling-related contamination calls for improved quality controls and novel approaches for the future of subseafloor research. Geomicrobiol J 27: 158-169.

Santelli CM, Edgcomb VP, Bach W, Edwards KJ. (2009). The diversity and abundance of bacteria inhabiting seafloor lavas positively correlate with rock alteration. Environ Microbiol 11: 86-98.

Santelli CM, Orcutt BN, Banning E, Bach W, Moyer CL, Sogin ML et al. (2008). Abundance and diversity of microbial life in ocean crust. Nature 453: 653-656.

Suzuki Y, Inagaki F, Takai K, Nealson KH, Horikoshi K. (2004). Microbial diversity in inactive chimney structures from deep-sea hydrothermal systems. Microb Ecol 47: 186-196.

Takai K, Nunoura T, Ishibashi J, Lupton J, Suzuki R, Hamasaki $\mathrm{H}$ et al. (2008). Variability in the microbial communities and hydrothermal fluid chemistry at the newly discovered Mariner hydrothermal field, southern Lau Basin. J Geophys Res 113: G02031.
Teske A, Hinrichs K-U, Edgecomb V, de Vera Gomez A, Kysela D, Sylva S et al. (2002). Microbial diversity of hydrothermal sediments in the Guaymas Basin: evidence for anaerobic methanotrophic communities. Appl Environ Microbiol 68: 1994-2007.

Toner BM, Lesniewski RA, Marlow JJ, Santelli CM, Bach $\mathrm{W}$, Orcutt $\mathrm{BN}$ et al. (in review). Mineralogy selects microbial community at low-temperature along the global mid-ocean ridge.

Toner BM, Santelli CM, Marcus MA, Wirth R, Chan CS, McCollom TM et al. (2009). Biogenic iron oxide formation at Mid-Ocean Ridge hydrothermal vents: Juan de Fuca Ridge. Geochim Cosmochim Acta 73: 388-403.

Wery N, Moricet J-M, Cueff V, Jean J, Pignet P, Lesongeur F et al. (2001). Caloranaerobacter azorensis gen. nov., sp. Nov., an anaerobic thermophilic bacterium isolated from a deep-sea hydrothermal vent. Int J Syst Evol Microbiol 51: 1789-1796.

Wheat CG, Elderfield H, Mottl MJ, Monnin C. (2000). Chemical composition of basement fluids within an oceanic ridge flank: Implications for along-strike and across-strike hydrothermal circulation. J Geophys Res 105: 13,437-13,447.

Wheat CG, Jannasch HW, Fisher AT, Becker K, Sharkey J, Hulme S. (2010). Subseafloor seawater-basalt-microbial reactions: continuous sampling of formation fluids in a ridge flank environment. Geochim Geophys Geosyst 11, Q07011, p 18.

Wheat CG, Jannasch HW, Kastner M, Plant JN, DeCarlo EH, Lebon G. (2004). Venting formation fluids from deep-sea boreholes in a ridge flank settings: OPD Sites 1025 and 1026. Geochem Geophys Geosys 5: Q08007.

Wheat CG, McManus J, Mottl MJ, Giambalyo E. (2003). Oceanic phosphorous imbalance: The magnitude of the ridge-flank hydrothermal sink. Geophys Res Lett 30: 1895.

Wheat CG, Mottl M. (2000). Composition of pore and spring waters from Baby Bare: global implications of geochemical fluxes from a ridge flank hydrothermal system. Geochim Cosmochim Acta 64: 629-642.

Supplementary Information accompanies the paper on The ISME Journal website (http://www.nature.com/ismej) 